\title{
'Bright-red' syndrome in Pacific white shrimp Litopenaeus vannamei is caused by Vibrio harveyi
}

\author{
Sonia A. Soto-Rodriguez*, Bruno Gomez-Gil, Rodolfo Lozano \\ CIAD, A.C. Mazatlan Unit for Aquaculture and Environmental Management, Av. Sabalo-Cerritos s/n Mazatlan, \\ Sinaloa 82010, Mexico
}

\begin{abstract}
Since July 2005, recurrent outbreaks of vibriosis have occurred in shrimp farms in northwestern Mexico. Moribund Litopenaeus vannamei associated with mass mortalities were lethargic and displayed red discoloration spots on their abdomen, and hence were called 'bright-reds' by farmers. Shrimp submitted for diagnosis were examined using wet tissue mounts, bacteriological assays and their respective minimum inhibitory concentration (MIC), and histology. A dominant yellow bacterial colony was isolated in thiosulphate citrate bile salts-sucrose (TCBS) agar and identified by molecular methods as Vibrio harveyi strain CAIM 1792. Pathogenicity of the V. harveyi strain was demonstrated in L. vannamei. The lowest MIC against Vibrio isolates from bright-red shrimp was obtained with enrofloxacine $\left(3.01, \mathrm{SD}=5.96 \mathrm{~g} \mathrm{ml}^{-1}\right)$. Histology detected severe necrosis in lymphoid organ tubules, muscle fibers, and connective tissue, as well as melanization and hemocytic nodules associate with microcolonies of Gram-negative bacilli. Bacteria from severely affected shrimp were dispersed from the haemocoel to other tissues causing a systemic vibriosis. The data indicate that $V$. harveyi strain CAIM 1792 is the cause of bright-red syndrome (BRS) and represents a threat to the Mexican shrimp farming industry.
\end{abstract}

KEY WORDS: Vibrio harveyi - Litopenaeus vannamei • Bright-red syndrome • rep-PCR . Shrimp culture · Histology

\section{INTRODUCTION}

Shrimp aquaculture has increased constantly over several decades and in 2006 accounted for as much as $70 \%$ of worldwide supply (FAO 2009). Mexico has become the third largest producer of farmed shrimp in the Western Hemisphere (Wurmann et al. 2004). This rapid increase in culture has often been impeded by severe disease epizootics. For example, diseases or syndromes associated with shrimp vibriosis have impacted Asia and America (Vandenberghe et al. 1998, Thompson et al. 2004, Soto-Rodriguez et al. 2006). During shrimp grow-out, many species have been associated with vibriosis, but only a few have been demonstrated to be the etiological agent, with others representing normal microbiota of the shrimp or the environment (Thompson et al. 2004). Vibrio strains proven to be pathogenic for shrimp include $V$. parahaemolyticus (red-leg disease syndrome; Alapide-Tendencia \& Dureza 1997), $V$. penaeicida (syndrome 93; Ishimaru et al. 1995), $V$. nigripulchritudo (summer syndrome; Goarant et al. 2006), V. alginolyticus (shell disease and loose shell syndrome; Jayasree et al. 2006), V. harveyi (AlapideTendencia \& Dureza 1997, de la Peña et al. 2001) and $V$. campbellii (Soto-Rodriguez et al. 2003, Rattanama et al. 2009, Lin et al. 2010).

Vibrio harveyi, which now includes $V$. carchariae and $V$. trachuri as junior synonyms (Pedersen et al. 1998, Thompson et al. 2002), is a serious pathogen of marine fish and invertebrates including flounder, abalone, seahorse, lobster, and sea cucumber among others (Diggles et al. 2000, Alcaide et al. 2001, Austin \& Zhang 2006, Rico et al. 2008).

Vibrio harveyi has been reported as one of the Vibrio species most commonly contributing to mass mortality during the grow-out of the tiger prawn Penaeus mon- 
odon (Jiravanichpaisal et al. 1994, Lavilla-Pitogo et al. 1998, Leaño et al. 1998). V. harveyi has also been recognized as a primary pathogen in larval stages often causing $100 \%$ mortality (Karunasagar et al. 1994, Alavandi et al. 2006). While many strains have been identified as $V$. harveyi using phenotypic methods, when analyzed using molecular methods, they were identified to be V. campbellii (Gomez-Gil et al. 2004, Thompson et al. 2007, Lin et al. 2010).

Although it is a serious pathogen of marine animals, no virulence factors have been established definitely for Vibrio species, and the extracellular products (ECPs) considered to be important determinants of $V$. harveyi virulence include hemolysins, proteases, and siderophores (Soto-Rodriguez et al. 2003, Zhong et al. 2006, Won \& Park 2008).

Vibriosis is an important disease of shrimp cultured in northwest Mexico and has caused recurrent outbreaks associated with mass mortalities for years (Soto-Rodriguez et al. 2010). Disease in Litopenaeus vannamei has been characterized by the appearance of bright red spots located bilaterally in the central region of the abdomen. Other signs observed include opacity of abdominal muscle, anorexia, lethargy, and death. Outbreaks were observed to occur mainly in the rainy season, affecting juvenile shrimp from about $5 \mathrm{~g}$ in weight up to adults. Larvae were tested before stocking to detect shrimp pathogens like infectious hypodermal hematopoietic necrosis virus (IHHNV), white spot syndrome virus (WSSV), Taura syndrome virus (TSV), yellow head virus (YHV), infectious myonecrosis virus (IMNV), and necrotizing hepatopancreatitis bacterium (NHPB). Affected farms have used oxytetracycline, florfenicol, and enrofloxacine to protect against mortality. A strain isolated from shrimp affected by bright-red syndrome (BRS) was recently identified as Vibrio harveyi by several molecular methods (Lin et al. 2010). The present study describes the disease caused by $V$. harveyi strain CAIM 1792 isolated from the lesion of a juvenile Litopenaeus vannamei shrimp affected by BRS.

\section{MATERIALS AND METHODS}

Sampling of diseased cultured shrimp. Juvenile shrimp Litopenaeus vannamei affected by BRS exhibiting reddish or white abdominal discoloration during a mass mortality event were collected and transported in plastic bags filled with pond water inside coolers and submitted for diagnosis at the Centro de Investigación en Alimentación y Desarrollo (CIAD). Samples were transported to CIAD as rapidly as possible, but if the transport was expected to take over $4 \mathrm{~h}$, ice cubes were placed around bags to lower the temperature. The average body weight of affected shrimp ranged from 8 to $10 \mathrm{~g}$ on the day of sampling. Gross disease signs were recorded, and shrimp samples were divided in groups to be analyzed for bacteriology, wet mount preparation, histology, and molecular viral detection. The Department of Aquaculture Pathology, University of Arizona, USA, kindly provided histology on shrimp affected by BRS to confirm our histological observations. The shrimp originated from farm ponds located in northwestern Mexico that had been stocked with L. vannamei at densities of 50 to 80 shrimp $\mathrm{m}^{2}$. The survey extended from July 2005 to September 2008 and included 3 shrimp farms that reported mortalities ranging from 20 to $70 \%$ during the culture cycle.

Bacteriological analysis. Each shrimp was weighed and disinfected with $70 \%$ ethanol. Haemolymph drawn from the ventral sinus was inoculated onto thiosulphate citrate bile salts-sucrose agar (TCBS, Difco) plates to enumerate vibrios. After removing the shell, a piece of hepatopancreas was weighted and homogenized in $10 \mathrm{ml}$ sterile $2.5 \% \mathrm{NaCl}$. Serial 10-fold dilutions of clarified supernatant were made, and $0.1 \mathrm{ml}$ was inoculated onto TCBS agar plates and incubated at $30^{\circ} \mathrm{C}$ for $24 \mathrm{~h}$. Colony forming units (CFUs) were counted; yellow colony numbers were recorded, and results were

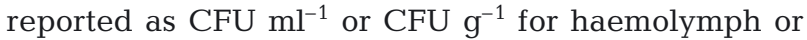
hepatopancreas, respectively. A total of 10 to 12 shrimp were analyzed from each pond sampled.

The minimum inhibitory concentration (MIC) was determined for 29 bacterial isolates in Müller-Hinton broth containing $2.5 \% \mathrm{NaCl}$ using a microdilution method (Rangdale et al. 1997, Soto-Rodriguez et al. 2010). Dominant yellow colonies picked from the TCBS plates were used to prepare a bacterial suspension to determine the MIC of oxytetracycline (OTC), enrofloxacine (ENR), florfenicol (FLO), and norfloxacine (NOR). All micro-well plates were incubated at $30^{\circ} \mathrm{C}$ for $24 \mathrm{~h}$.

Histological analysis. Tissue samples taken from 6 shrimp per pond were preserved in Davidson's fixative for $48 \mathrm{~h}$ and then processed by routine histology (Bell \& Lightner 1988). Tissue sections were stained with hematoxylin and eosin (H\&E). Giemsa and GramHumberstone stains were used in some tissue sections.

Isolation of bacteria and molecular characterization. Yellow colonies picked from TCBS plates inoculated with haemolymph or from lesions were purified on tryptic soy agar (TSA, Bioxon) supplemented with $2.0 \% \mathrm{NaCl}$ and incubated at $30^{\circ} \mathrm{C}$ for 18 to $24 \mathrm{~h}$. All isolates were preserved in cryovials at $-70^{\circ} \mathrm{C}$ according to the method described by Gherna (1994).

Four representative isolates were deposited in the Collection of Aquatic Important Microorganisms (CAIM, CIAD Mazatlan, www.ciad.mx/caim) as CAIM 1792, CAIM 1793, CAIM 1794, and CAIM 1795. CAIM 
1792 was isolated from the lesion of a juvenile shrimp, and the others from the haemolymph of another shrimp. The isolates were DNA fingerprinted by repPCR analysis as described previously (CabanillasBeltran et al. 2006). Briefly, genomic DNA extracted with the Wizard DNA extraction kit (Promega) and adjusted to $50 \mathrm{ng}^{-1} \mathrm{l}^{-1}$ was DNA fingerprinted by repPCR using the $(\mathrm{GTG})_{5}$ primers and the Taq DNA polymerase enzyme (Promega). The DNA bands obtained were separated by electrophoresis in a $1.2 \%$ agarose gel stained with ethidium bromide and visualized using a UVP' ${ }^{\mathrm{TM}}$ gel documentation system.

Experimental infection. Inoculum preparation: Strain CAIM 1792 recovered from cryovials was inoculated into TSA $+2.0 \% \mathrm{NaCl}$ and incubated overnight at $30^{\circ} \mathrm{C}$. Several colonies were resuspended in sterile $2.5 \% \mathrm{NaCl}$ and centrifuged at $5724 \times g$ for $10 \mathrm{~min}$ at $15^{\circ} \mathrm{C}$. The clarified bacterial suspension was adjusted to an optical density of 1.0 at $610 \mathrm{~nm}$, equivalent to 0.5 MacFarland standard $\left(10^{8} \mathrm{CFU} \mathrm{m}^{-1}\right)$ (Soto-Rodriguez et al. 2003) and serially diluted to estimated densities of $10^{6}$ and $10^{7} \mathrm{CFU} \mathrm{ml}{ }^{-1}$. The suspensions were plated onto TCBS plates to determine the actual density of Vibrio harveyi used to challenge shrimp.

Bacterial challenge: Juvenile shrimp were transported from a local farm to the laboratory, acclimated for $1 \mathrm{wk}$, and over $3 \mathrm{~d}$ their health status was evaluated and the bacteria in the water were detected by plating samples onto marine agar (MA). Before challenge, haemolymph was sampled from randomly selected shrimp, and total heterotrophic bacteria and vibrios loads were quantified on MA and TCBS plates, respectively.

The challenge system used $60 \mathrm{l}$ glass aquaria filled with $10 \mu \mathrm{m}$-filtered, UV-sterilized, aerated seawater at 28 to $30^{\circ} \mathrm{C}$ and a $12 \mathrm{~h}$ photoperiod. The third abdominal segment of shrimp weighing $10.4 \mathrm{~g}, \mathrm{SD}=0.4 \mathrm{~g}$ was injected with $100 \mu \mathrm{l} 1.3 \times 10^{6}$ or $1.3 \times 10^{7} \mathrm{CFU}$ per shrimp of strain CAIM 1792 or with $100 \mu$ sterile saline solution (control group). Three replicate aquaria each containing 6 shrimp were used. Experimental aquaria were allocated randomly and maintained for $10 \mathrm{~d}$.

Shrimp were fed ad lib twice each day with a commercial (Purina ${ }^{\mathrm{TM}}$ ) diet of $35 \%$ protein. Temperature, nitrates, total ammonia, salinity, $\mathrm{pH}$, and mortalities in each aquarium were recorded daily.

Vibrio re-isolation and molecular identification. Haemolymph from moribund shrimp was inoculated onto TCBS agar plates immediately after shrimp tissues were preserved in Davidson's fixative. TCBS plates were incubated at $30^{\circ} \mathrm{C}$ for $24 \mathrm{~h}$, and dominant yellow colonies that grew were DNA fingerprinted by rep-PCR (Cabanillas-Beltran et al. 2006). Fixed tissue samples were processed for histology and examinated using standard procedures (Bell \& Lightner 1988).

\section{RESULTS}

\section{Farmed shrimp}

From July 2005 to September 2008, a total of 41 batches of 5 to 12 shrimp were sampled from 3 farms. Of these sample batches, 16 were examinated by PCR, 8 by histology, 9 by bacteriological analyses, 5 by MIC analysis, and 3 by wet mount analysis. Shrimp were examinated only when BRS had occurred in association with sudden mortality events in which moribund shrimp were seen floating on the water surface or caught in the discharge screens. Shrimp affected by BRS presented various gross signs depending on infection severity that included lethargic swimming, anorexic, flaccid body, opacity of the abdominal muscle, and reddish discoloration spots on the cuticle sometimes with melanized erosions around the spots (Fig. 1). Farm managers also reported that crabs living around affected ponds showed similar red spots on their shells, but no crab samples were submitted for examination. Outbreaks were observed mainly during the rainy season, from July to October, when salinity decreased to about 10 to $15 \mathrm{~g} \mathrm{l}^{-1}$. Some farmers used medicated feed to control the mortalities with variable success depending on dose, frequency of application, and the antibiotic used.

\section{Bacteriological analyses}

In total, 103 shrimp were analyzed for bacteriology (Table 1). TCBS plates inoculated with haemolymph grew a dominant yellow colony that was flat, round with undulated borders, and about 2 to $3 \mathrm{~mm}$ in diameter (Fig. 2).

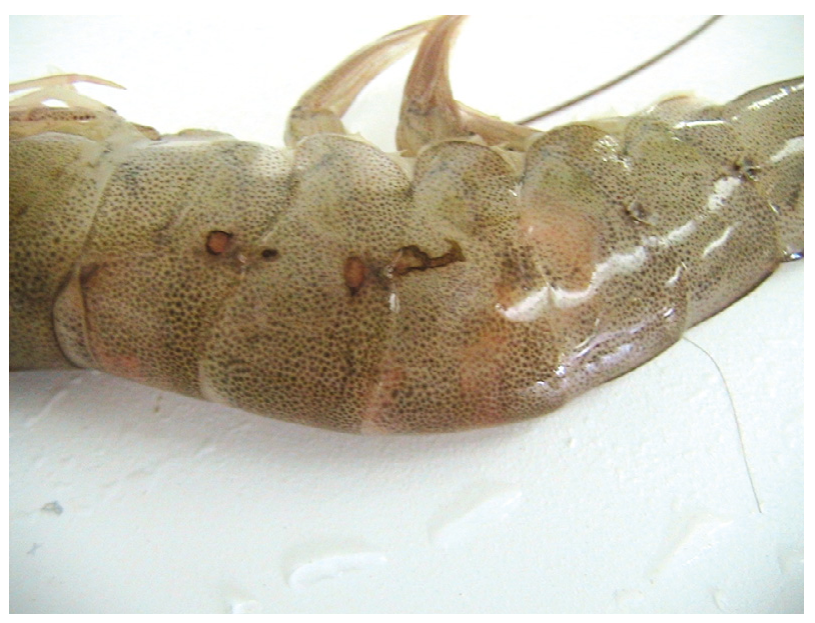

Fig. 1. Litopenaeus vannamei. A shrimp with bright-red syndrome (BRS) showing typical gross signs, opacity, and red discoloration spots on the abdominal cuticle, sometimes with melanization around the spots 
Table 1. Vibrio harveyi densities in the haemolymph and hepatopancreas of Litopenaeus vannamei affected by bright-red syndrome (BRS) and yellow colonies (YC) that grew in thiosulphate citrate bile salts-sucrose (TCBS) plates. HL: haemolymph; HP: hepatopancreas

\begin{tabular}{|lcccc|}
\hline & Mean (n=103) & SD & Max. & Min. \\
\hline Weight (g) & 7.8 & 2.9 & 17.7 & 1.9 \\
Vibrio HL $\left(\mathrm{CFU} \mathrm{m}^{-1}\right.$ ) & $2.35 \times 10^{3}$ & $6.31 \times 10^{3}$ & $4.3 \times 10^{4}$ & 0.0 \\
Vibrio HP (CFU g $^{-1}$ ) & $1.89 \times 10^{5}$ & $2.60 \times 10^{5}$ & $1.9 \times 10^{6}$ & 0.0 \\
YC HL (\%) TCBS $_{\text {YC HP (\%) TCBS }}$ & 74.3 & 39.8 & & \\
\hline
\end{tabular}

MICs were determinate for some shrimp samples examinated in bacteriological analysis. Wide fluctuations in antibiotic concentrations were observed in order of lowest to highest MIC values, ENR (3.01, SD = $\left.5.96 \mu \mathrm{g} \mathrm{ml}^{-1}\right)$, NOR $\left(5.48, \mathrm{SD}=8.32 \mu \mathrm{g} \mathrm{ml}^{-1}\right)$, FLO $(9.33$, $\left.\mathrm{SD}=11.55 \mu \mathrm{g} \mathrm{ml}^{-1}\right)$, and OTC $(93.01, \mathrm{SD}=53.45 \mu \mathrm{g}$ $\mathrm{ml}^{-1}$ ).

Wet mount examination of the gills of 50 Litopenaeus vannamei with BRS revealed low (G1-G2; Lightner 1996) infestations of epicomensals, mainly Zoothamium sp., reddish spots in the cuticle, red to dark red uropods, opacity of the muscle, and melanization under the cuticle. Necrotic abdominal muscle fibers with melanized areas under the melanized cuticle were also observed.

\section{Histological analysis of shrimp affected by BRS}

Lesions in farmed shrimp affected by BRS were characterized by multifocal ulcerations of the abdominal cuticle including erosion and melanization, large hemocytic infiltrations, hemocytic nodules, in some cases melanized in response to abundant microcolonies of Gram-negative bacteria which were colonizing the striated muscle, lymphoid organ (LO), antennal glandule, heart, stomach epithelium, and hepatopancreas. Melanized cuticle areas of 36 Litopenaeus vannamei displayed lesions in the striated muscle that focally affected the cuticle epithelium and connective tissue around the lesion site (Fig. 3a). The lesion is characterized by severe necrosis of connective tissue and muscle packs, hemocytic infiltration (Fig. 3b), and hemocytic nodules associate with numerous dispersed bacilli through the muscle fibers (Fig. 3c).

Severally affected shrimp showed bacteria dispersed from the haemocele to the connective tissue and stomach epithelium (Fig. 3d), antennal glandule (Fig. 3e), heart (Fig. 3f), gills, and connective tissue of hepatopancreas. Tissues showed an inflammatory response with hemocytic infiltration and aggregation around bacteria. Pyknotic hemocytes with melanin deposits occurred commonly.
LO is the second most affected tissue after the striated muscle, and was severely necrotized (Fig. 4a). LO tubules displayed a loss of the stromal matrix of cells associated with a change in the organ morphology due to a severe necrosis and hemocytic infiltration, probably caused by the abundance of Gram-negative bacilli dispersed throughout the tissue (Fig. 4b). In Case 06-346, a systemic bacterial infection occurred as plaques and in haemolymph circulating between necrotic skeletal muscle and in other organs including nerve cord and the antennal gland. Multifocal necrosis with necrotic cells exhibiting pyknotic nuclei was also evident in LO, suggesting the bacterium was the cause of this histopathology. No LO spheroids characteristic of infection by IMNV and Litopenaeus vannamei nodavirus (LvNV) were evident in any shrimp examined.

WSSV, IHHNV, and TSV IQ2000 ${ }^{\mathrm{TM}}$ PCR tests performed on pieces of gills and pleopods pooled from 16 batches of shrimp detected WSSV in 13 batches, TSV in 2 batches, and IHHNV in 1 batch.

\section{Molecular characterization}

The rep-PCR banding patterns obtained from the 4 isolates characterized were identical (Fig. 5), indicating that a single Vibrio strain had been isolated from both lesions and haemolymph of 2 shrimp from separate BRS events. This strain was also isolated from other BRS events in different years (data not shown), at the same farm, and from other farms in the same region.

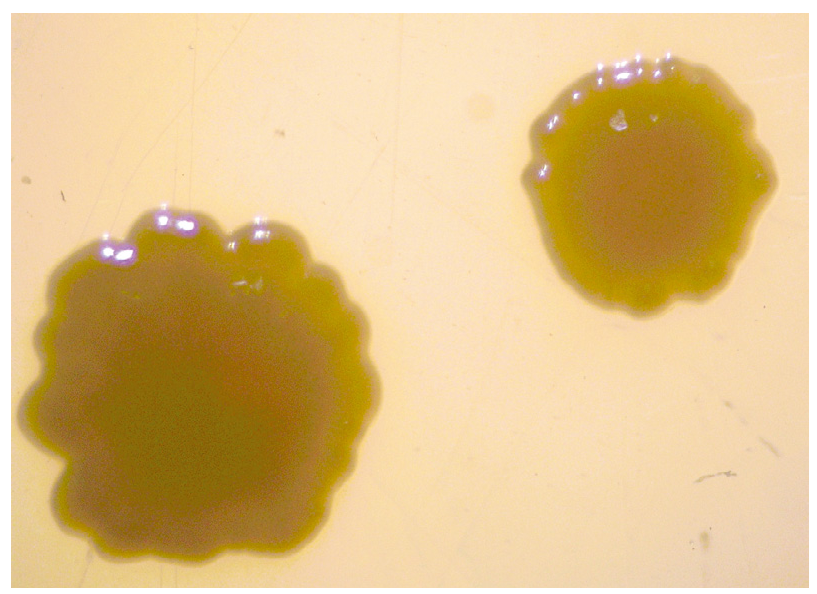

Fig. 2. Vibrio harveyi. Colonies of strain CAIM 1792 showing flat and round morphology with undulated borders 

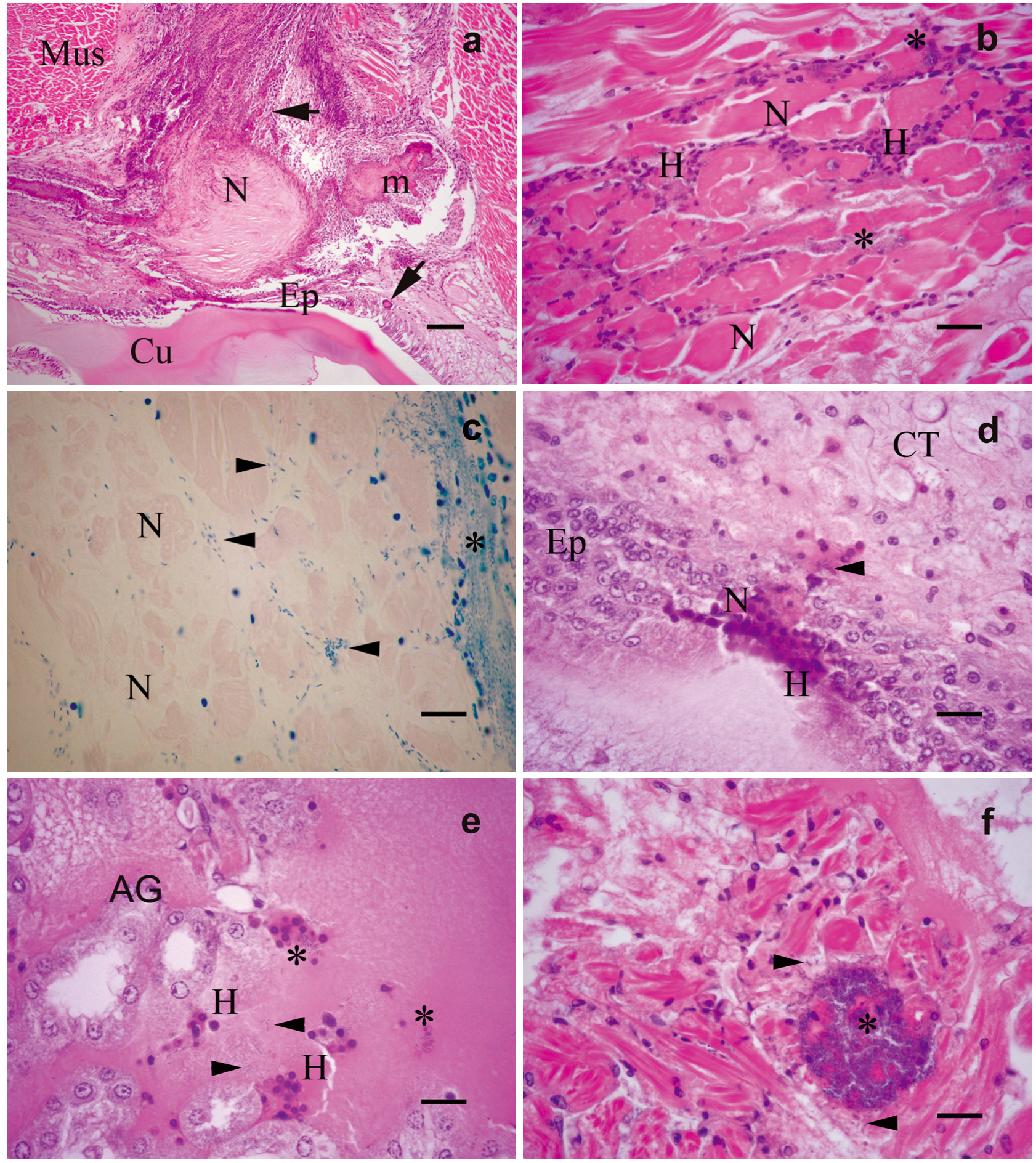

Fig. 3. Litopenaeus vannamei. $(\mathrm{a}, \mathrm{b}, \mathrm{c})$ Microphotographs of striated muscle (Mus) of shrimp naturally affected by bright-red syndrome (BRS). (a) Transversal section through a typical BRS lesion from the second abdominal somite displaying deformed cuticle $(\mathrm{Cu})$, necrosis $(\mathrm{N})$ of cuticle epithelium $(\mathrm{Ep})$, connective tissue, and muscle fibers with large hemocytic infiltrations, melanization (m) and small melanizated hemocytic nodules (arrows). (b) Longitudinal section of striated muscle showing hemocytic infiltration $(\mathrm{H})$, severe necrosis $(\mathrm{N})$ of muscle fibers with bacteria (asterisks) that have colonized the lesion in the necrotic tissue. (c) Bacterial masses (asterisk) and dispersed bacteria (arrowheads) in striated muscle observed in necrotic muscle fibers (N). (d,e) Hemocytic infiltration $(\mathrm{H})$ in response to bacterial masses (asterisks) and disperse bacteria (arrowheads) in connective tissue (CT), stomach epithelium (Ep), and antennal glandule (AG). (f) Cardiac muscle with bacteria, accumulation (asterisk), and dispersed (arrowheads). (a,b,d,e,f) H\&E stain; (c) Giemsa stain. Scale bar = (a) $100 \mu \mathrm{m},(\mathrm{b}, \mathrm{c}, \mathrm{d}, \mathrm{e}, \mathrm{f}) 20 \mu \mathrm{m}$ 

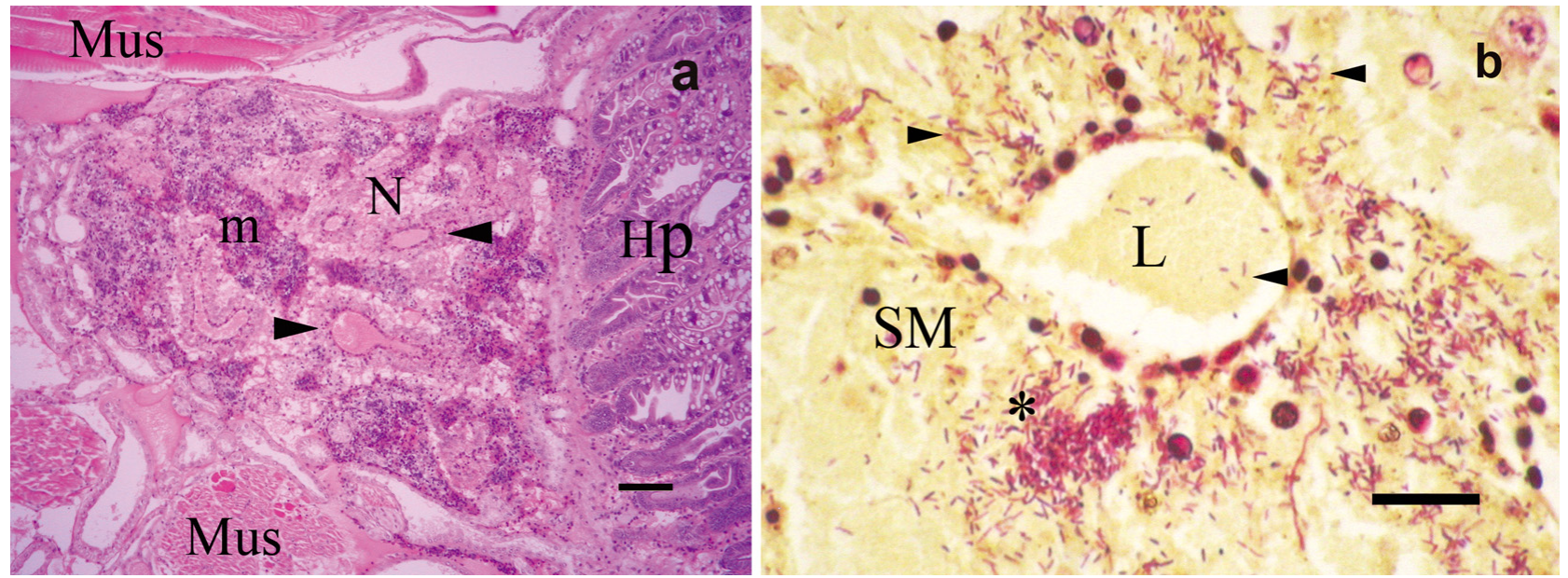

Fig. 4. Litopenaeus vannamei. (a) Longitudinal view showing lymphoid organ (LO) adjacent to hepatopancreas (Hp) and striated muscle (Mus) with severe necrosis (N), with a reduction of the stromal matrix (SM) of cells (arrowheads), hemocytic infiltration, and melanization $(\mathrm{m})(\mathrm{H} \& \mathrm{E}$ stain; scale bar $=100 \mu \mathrm{m})$. (b) Enlarged view of a LO tubule displaying Gram-negative bacterial colonization that was visible as masses (asterisk) in the SM and dispersed (arrowheads) inside the lumen (L). Gram Humberstone stain; scale bar $=20 \mu \mathrm{m}$

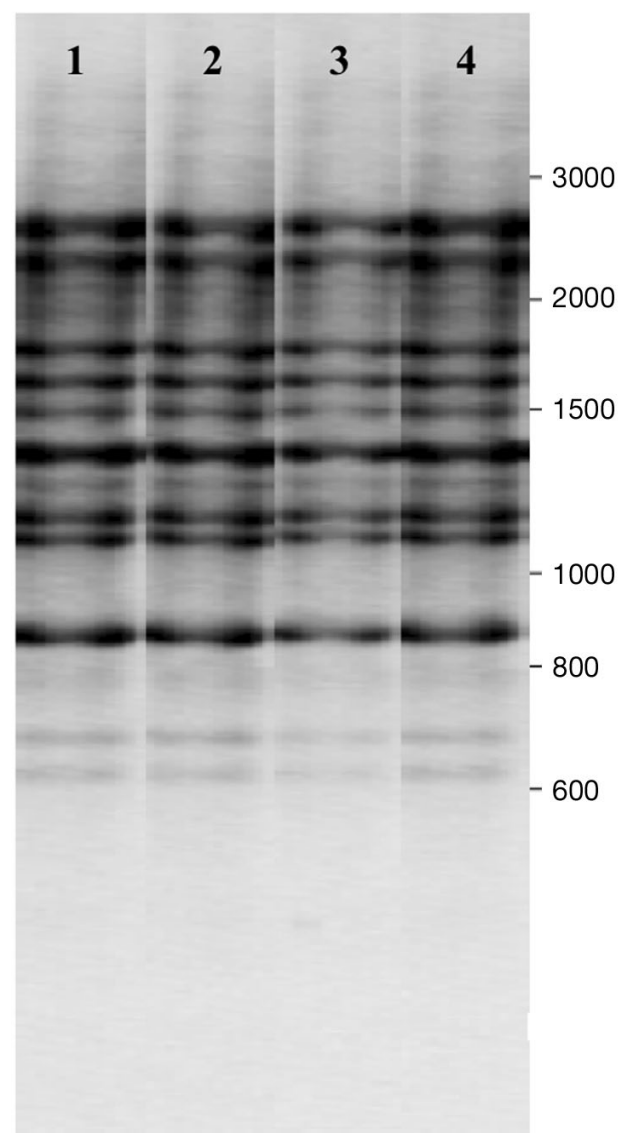

Fig. 5. Vibrio strains. rep-PCR DNA banding pattern of 4 Vibrio strains isolated from bright red syndrome (BRS)-affected shrimp including CAIM 1792 (lane 1), CAIM 1793 (lane 2), CAIM 1794 (lane 3), and CAIM 1795 (lane 4). Numbers denote DNA length (bp)

\section{Experimental infection}

In the experimental aquaria (water temperature $=28$ to $30^{\circ} \mathrm{C}$, salinity $=38$ to $39 \mathrm{~g} \mathrm{l}^{-1}, \mathrm{pH}=8.3 \pm 0.2$, total ammonium $\leq 0.8 \mathrm{mg} \mathrm{l}^{-1}$, nitrites $\leq 0.4 \mathrm{mg} \mathrm{l}^{-1}$ ) no vibrios were detected in intake water during the bioassay or in haemolymph of shrimp sampled before challenge.

The gross signs in challenged shrimp were lethargy, erratic swimming (whirling movement), and flaccid body by $1 \mathrm{~h}$ post-injection (pi). Shrimp injected with $10^{7} \mathrm{CFU}$ of bacteria died before $2.5 \mathrm{~h}$ pi. However, in shrimp injected with $10^{6} \mathrm{CFU}$ of bacteria, opacity developed at the site of injection by $24 \mathrm{~h}$ pi. No mortality occurred in the control shrimp. The Vibrio density in haemolymph of moribund shrimp examined was $1.21 \times 10^{3}, \mathrm{SD}=1.27 \times$ $10^{2} \mathrm{CFU} \mathrm{m}{ }^{-1}$. A dominant yellow colony grew on TCBS plates inoculated with haemolymph of challenged shrimp. Bacteria fingerprinted by rep-PCR displayed the same DNA banding pattern as the injected strain (CAIM 1792). No vibrios were detected in haemolymph sampled from control shrimp.

\section{Histopathology in experimentally infected shrimp}

Histopathology in shrimp infected with Vibrio was similar to that observed in farmed shrimp affected by BRS (Fig. 6). Around the site of injection, necrotic fibers in the striated muscle, hemocytic infiltration, and Gram-negative bacteria (clustered and dispersed) were observed. In addition, LO was severely necrotized displaying loss of cellular stromal matrix, abundant Gramnegative bacteria, and hemocytic infiltration. 

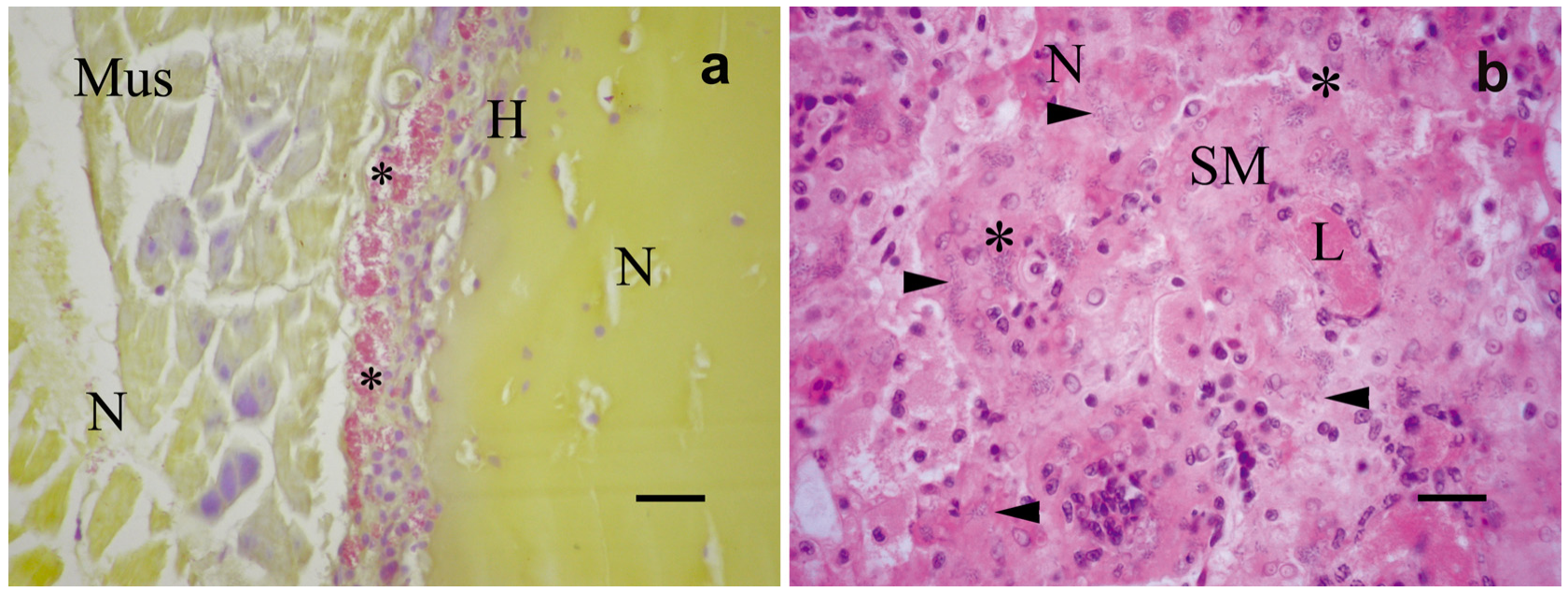

Fig. 6. Microphotographs of Litopenaeus vannamei challenged with Vibrio harveyi at $10^{7}$ CFU per shrimp. (a) Transversal view of striated muscle (Mus) at site of the injection showing a hemocytic infiltration $(\mathrm{H})$ and microcolonies of Gram-negative bacteria (asterisks) visible in necrotic muscle fibers (N). Gram Humberstone; scale bar $=20 \mu \mathrm{m}$. (b) Severe necrosis (N) of the lymphoid organ tubule and loss of the stromal matrix (SM) of cells; bacteria were colonizing the tissue as masses (asterisks) or were dispersed (arrowheads). L: lumen. H\&E stain; scale bar $=20 \mu \mathrm{m}$

\section{DISCUSSION}

Farmed Litopenaeus vannamei shrimp affected by BRS can display lethargic swimming, anorexia, a flaccid body, multifocal reddish discoloration spots on the abdominal cuticle, sometimes with melanized erosions around the spots, and white opacity of the abdominal muscle. These signs are similar to those of vibriosis observed generally in penaeid shrimp, but red spots on the abdominal cuticle have not been reported before and differ from black spots syndrome or other shell diseases.

Prior to this study, farmers suspected that shrimp with signs of BRS might be co-infected with WSSV and an unknown virus due to its association with sudden mortalities as typically observed in shrimp infected with WSSV. Whilst WSSV was sometimes detected during outbreaks of BRS, vibriosis was always present with the CAIM 1792 strain predominating in the haemolymph of all shrimp sampled. The density of vibrio in haemolymph and the hepatopancreas was similar to Litopenaeus vananmei shrimp with vibriosis cultured in northwestern Mexico (Soto-Rodriguez et al. 2010).

Histology in shrimp affected by BRS confirmed vibriosis with the main target tissues being the striated muscle and the LO. Severe necrosis of the LO tubules and the muscle fibers underlying the LO ulcerated cuticle was observed. In contrast, generalized atrophy of the hepatopancreas and multifocal melanized and/or non-melanized hemocytic nodules with septic centers are the diagnostic features commonly associated with systemic vibriosis in cultured shrimp. Such nodules are most common in the LO, heart, and gills, but may be present elsewhere in haemocele spaces and in the loose connective tissues (Mohney et al. 1994, Lightner 1996, Esteve \& Herrera 2000).

Mexican shrimp farmers commonly use antibiotics to control vibriosis, traditionally OTC and quinolones ENR and NOR (Lyle-Fritch et al. 2006). However, the overuse of antibiotics in aquaculture may cause antibiotic resistance to develop with bacterial pathogens. Multiple antibiotic-resistant Vibrio species have been reported in Asia (Tendencia \& de la Peña 2001). Most studies have examinated pure strains of Vibrio rather than Vibrio isolated from diseased shrimp. Roque et al. (2001) determined MICs of Vibrio spp. isolated from diseased shrimp from the same geographical area of the present study, and found MIC values at least 3-fold increased for OTC and MIC values 8- to 9-fold decreased for ENR and FLO. However, the Roque et al. (2001) study was undertaken over a decade ago (1996-1998), when shrimp farmers predominantly used OTC to control vibriosis, and as resistance to OTC is plasmid-mediated, it can be quickly acquired and lost (Adams et al. 1998).

The majority of MICs against Vibrio strains isolated from diseased shrimp determined for OTC have ranged from 0.125 to above $100 \mu \mathrm{g} \mathrm{ml}^{-1}$ (Baticados et al. 1990, Akinbowale et al. 2006) and MICs for ENR and FLO have ranged from 0.05 to $1.0 \mu \mathrm{g} \mathrm{ml}^{-1}$ and 0.5 to $4.0 \mu \mathrm{g}$ $\mathrm{ml}^{-1}$, respectively (Mohney et al. 1992). These MIC values are lower than determined here; however, again they were determined for pure strains of Vibrio spp. rather than total Vibrios from diseased shrimp.

Injection of CAIM 1792 at $10^{7} \mathrm{CFU}$ per shrimp resulted in rapid mortality without clinical signs or gross pathological changes, whilst injection of $10^{6} \mathrm{CFU}$ per shrimp generated mortality rates and clinical signs sim- 
ilar to BRS. Histopathology was typified by severe necrosis in striated muscle at the site of injection and necrosis and loss of the stromal matrix of cells in the LO. The LO functions as a filter for foreign material encountered in the haemolymph (Van de Braak et al. 2002) and plays a role in Vibrio uptake and bacteriostasis in Litopenaeus vannamei (Burgents et al. 2005). As a consequence, the shrimp LO is commonly damaged during vibriosis due to the accumulation of bacteria. Microcolonies of Gram-negative bacteria were also present in striated muscle, LO, antennal glandule, heart, stomach epithelium, connective tissue, and hepatopancreas of moribund shrimp, and these bacterial clumps appear to occur due to the bacteria being recognized as foreign bodies by hemocytes that become sticky and adherent.

In shrimp challenged with Vibrio harveyi CAIM 1792, a predominant bacterium was re-isolated from haemolymph and characterized by rep-PCR to be the same as the injected bacteria. Histopathology in shrimp experimentally infected with vibrios commonly involves a loss of structure of the hepatopancreas and clusters of hemocytes in connective tissue, mostly loaded with bacteria (Jiravanichpaisal et al. 1994, Lightner 1996, Esteve \& Herrera 2000). There is evidence that some $V$. harveyi strains are capable of producing ECPs responsible for their pathogenicity for a variety of marine species (Austin \& Zhang 2006). ECPs of pathogenic isolates might contain proteases, gelatinases, phospholipases, siderophores, and haemolysins (Zhang \& Austin 2000, Soto-Rodriguez et al. 2003, Won $\&$ Park 2008). The mechanisms of pathogenicity used by $V$. harveyi causing BRS might involve bacterial colonization due the bacteria's ability to attach and form biofilms (Austin \& Zhang 2006), form ulcers on cuticle by producing chitinases (Defoirdt et al. 2010), and its systemic distribution via haemolymph.

The data reported here demonstrates that Vibrio harveyi strain CAIM 1792 is the etiological agent of BRS in cultured Litopenaeus vannamei sampled between 2005 and 2008. Jayasree et al. (2006) suggest that virulence of $V$. harveyi is dependent on the source of the isolate and the culture conditions used for its isolation. However, V. harveyi strain CAIM 1792 was repeatedly detected in shrimp sampled over this period from different farms. It is possible that this strain can become dormant, living in the sediment of ponds during culture cycles, and then resuscitate under favorable conditions retaining its pathogenic potential (Sun et al. 2008).

Acknowledgements. This study was in part supported by shrimp farmer's contributions. We thank Carlos Pantoja (University of Arizona) for providing histology data, C. Bolan and F. Marrujo for technical assistance, N. Duncan for reviewing the grammar, and S. Escutia for donating Litopenaeus vannamei.

\section{LITERATURE CITED}

Adams CA, Austin B, Meaden PG, McIntosh D (1998) Molecular characterization of plasmid-mediated oxytetracycline resistance in Aeromonas salmonicida. Appl Environ Microbiol 64:4194-4201

Akinbowale OL, Peng H, Barton MD (2006) Antimicrobial resistance in bacteria isolated from aquaculture sources in Australia. J Appl Microbiol 100:1103-1113

Alapide Tendencia EV, Dureza LA (1997) Isolation of Vibrio spp. from Penaeus monodon (Fabricius) with red disease syndrome. Aquaculture 154:107-114

Alavandi SV, Manoranjita V, Vijayan KK, Kalaimani N, Santiago TC (2006) Phenotypic and molecular typing of Vibrio harveyi isolates and their pathogenicity to tiger shrimp larvae. Lett Appl Microbiol 43:566-570

Alcaide E, Gil-Sanz C, Sanjuán E, Esteve D, Amaro C, Silveira L (2001) Vibrio harveyi causes disease in seahorse, Hippocampus sp. J Fish Dis 24:311-313

Austin B, Zhang XH (2006) Vibrio harveyi: a significant pathogen of marine vertebrates and invertebrates. Lett Appl Microbiol 43:119-124

> Baticados MCL, Lavilla Pitogo CR, Cruz Lacierda ER, de la Peña LD, Suñaz NA (1990) Studies on the chemical control of luminous bacteria Vibrio harveyi and V. splendidus isolated from diseased Penaeus monodon larvae and rearing water. Dis Aquat Org 9:133-139

Bell TA, Lightner DV (1988) A handbook of normal shrimp histology. Spec Pub No. 1, World Aquaculture Society Baton Rouge, LA

Burgents JE, Burnetta LE, Stabbb EV, Burnett KG (2005) Localization and bacteriostasis of Vibrio introduced into the Pacific white shrimp, Litopenaeus vannamei. Dev Comp Immunol 29:681-691

Cabanillas-Beltran H, LLausas-Magana E, Romero R, Espinoza A and others (2006) Outbreak of gastroenteritis caused by the pandemic Vibrio parahaemolyticus O3:K6 in Mexico. FEMS Microbiol Lett 265:76-80

de la Peña LD, Lavilla-Pitogo CR, Paner MG (2001) Luminescent vibrios associated with mortality in pond-cultured shrimp Penaeus monodon in the Philippines: species composition. Fish Pathol 36:133-138

Defoirdt T, Darshanee Ruwandeepika HA, Karunasagar I, Boon N, Bossier P (2010) Quorum sensing negatively regulates chitinase in Vibrio harveyi. Environ Microbiol Rep 2:44-49

> Diggles BK, Moss GA, Carson J, Anderson CD (2000) Luminous vibriosis in rock lobster Jasus verreauxi (Decapoda: Palinuridae) phyllosoma larvae associated with infection by Vibrio harveyi. Dis Aquat Org 43:127-137

Esteve C, Herrera FC (2000) Hepatopancreatic alterations in Litopenaeus vannamei (Boone, 1931) (crustacea: decapoda: penaeidae) experimentally infected with Vibrio alginolyticus strain. J Invertebr Pathol 76:1-5

FAO (Food and Agriculture Organization of the United Nations) (2009) The state of world fisheries and aquaculture 2008. Fisheries and Aquaculture Department, Rome

Gherna LR (1994) Culture preservation. In: Gerhardt P, Murray REG, Wood WA, Krieg NR (eds) Methods for general and molecular bacteriology. American Society for Microbiology, Washington, DC, p 278-292

> Goarant C, Reynaud Y, Ansquer D, de Decker S, Saulnier D, le Roux F (2006) Molecular epidemiology of Vibrio nigripulchritudo, a pathogen of cultured penaeid shrimp (Litopenaeus stylirostris) in New Caledonia. Syst Appl Microbiol 29:570-580 
Gomez-Gil B, Soto-Rodriguez S, Garcia-Gasca A, Roque A, Vazquez-Juarez R, Thompson FL, Swings J (2004) Molecular identification of Vibrio harveyi-related isolates associated with diseased aquatic organisms. Microbiology 150: 1769-1777

Ishimaru K, Matsushita MA, Muroga K (1995) Vibrio penaeicida sp. nov., a pathogen of kuruma prawns (Penaeus japonicus). Int J Syst Bacteriol 45:134-138

Jayasree L, Janakiram P, Madhavi RT (2006) Characterization of Vibrio spp. associated with diseased shrimp from culture ponds of Andhra Pradesh (India). J World Aquacult Soc 37:523-532

Jiravanichpaisal P, Miyazaki T, Limsuwan C (1994) Histopathology, biochemistry, and pathogenicity of Vibrio harveyi infecting black tiger prawn Penaeus monodon. J Aquat Anim Health 6:27-35

Karunasagar I, Pai R, Malathi GR, Karunasagar I (1994) Mass mortality of Penaeus monodon larvae due to antibiotic-resistant Vibrio harveyi infection. Aquaculture 128:203-209

Lavilla-Pitogo CR, Leaño EM, Paner MG (1998) Mortalities of pond-cultured juvenile shrimp, Penaeus monodon, associated with dominance of luminescent vibrios in the rearing environment. Aquaculture 164:337-349

Leaño EM, Lavilla Pitogo CR, Paner MG (1998) Bacteria flora in the hepatopancreas of pond-reared Penaeus monodon juveniles with luminous vibriosis. Aquaculture 164:367-374

Lightner DV (1996) A handbook of shrimp pathology and diagnostic procedures for diseases of cultured penaeid shrimp. World Aquaculture Society, Baton Rouge, LA

Lin B, Wang Z, Malanoski AP, O'Grady EA and others (2010) Comparative genomic analyses identify the Vibrio harveyi genome sequenced strains BAA-1116 and HY01 as Vibrio campbellii. Environ Microbiol Rep 2:81-89

Lyle-Fritch LP, Romero-Beltran E, Paez-Osuna F (2006) A survey on use of the chemical and biological products for shrimp farming in Sinaloa (NW Mexico). Aquacult Eng 35:135-146

Mohney LL, Bell TA, Lightner DV (1992) Shrimp antimicrobial testing. I. In vitro susceptibility of thirteen gram-negative bacteria to twelve antimicrobials. J Aquat Anim Health 4:257-261

Mohney LL, Lightner DV, Bell TA (1994) An epizootic of vibriosis in Ecuadorian pond-reared Penaeus vannamei Boone (Crustacea: Decapoda). J World Aquacult Soc 25: 116-125

Pedersen K, Verdonck L, Austin B, Austin DA and others (1998) Taxonomic evidence that Vibrio carchariae is a junior synonym of Vibrio harveyi. Int J Syst Bacteriol 48: 749-758

Rangdale RE, Richards RH, Alderman DJ (1997) Minimum inhibitory concentrations of selected antimicrobial compounds against Flavobacterium psychrophilum the causal agent of rainbow trout fry syndrome (RTFS). Aquaculture 158:193-201

Rattanama P, Srinitiwarawong K, Thompson JR, Pomwised R, Supamattaya K, Vuddhakul V (2009) Shrimp pathogenicity, hemolysis, and the presence of hemolysin and TTSS genes in Vibrio harveyi isolated from Thailand. Dis Aquat Org 86:113-122

Editorial responsibility: Jeff Cowley, Brisbane, Queensland, Australia
Rico RM, Tapia-Paniagua S, Martínez-Manzanares E, Balebona MC, Moriñigo MA (2008) Characterization of Vibrio harveyi strains recovered from diseased farmed Senegalese sole (Solea senegalensis). J Appl Microbiol 105: $752-760$

Roque A, Molina-Aja A, Bolán-Mejía C, Gomez-Gil B (2001) In vitro susceptibility to 15 antibiotics of vibrios isolated from penaeid shrimps in northwestern Mexico. Int J Antimicrob Agents 17:383-387

Soto-Rodriguez S, Gomez-Gil B, Roque A, Lizarraga-Partida L (2003) Virulence of luminous vibrios to Artemia nauplii. Dis Aquat Org 53:231-240

Soto-Rodriguez SA, Simoes N, Roque A, Gomez-Gil B (2006) Pathogenicity and colonization of Litopenaeus vannamei larvae by luminescent vibrios. Aquaculture 258:109-115

> Soto-Rodriguez S, Gomez-Gil B, Lozano R, Roque A (2010) Density of vibrios in hemolymph and hepatopancreas of diseased Pacific white shrimp, Litopenaeus vannamei, from northwestern Mexico. J World Aquacult Soc 41: 76-83

Sun F, Chen J, Zhong L, Zhang XH, Wang R, Guo Q, Dong Y (2008) Characterization and virulence retention of viable but nonculturable Vibrio harveyi. FEMS Microbiol Ecol 64:37-44

- Tendencia EA, de la Peña L (2001) Antibiotic resistance of bacteria from shrimp ponds. Aquaculture 195:193-204

> Thompson FL, Hoste B, Vandemeulebroecke K, Engelbeen K, Denys R, Swings J (2002) Vibrio trachuri Iwamoto et al. 1995 is a junior synonym of Vibrio harveyi (Johnson and Shunk 1936) Baumann et al. 1981. Int J Syst Evol Microbiol 52:973-976

> Thompson FL, Iida T, Swings J (2004) Biodiversity of vibrios. Microbiol Mol Biol Rev 68:403-431

> Thompson FL, Gomez-Gil B, Ribeiro Vasconcelos AT, Sawabe $\mathrm{T}$ (2007) Multilocus sequence analysis reveals that Vibrio harveyi and V. campbellii form distinct species. Appl Environ Microbiol 73:4279-4285

Van de Braak CBT, Botterblom MHA, Taverne N, Van Muiswinkel WBJ, Rombout HWM, Van der Knaap WPW (2002) The roles of haemocytes and the lymphoid organ in the clearance of injected Vibrio bacteria in Penaeus monodon shrimp. Fish Shellfish Immunol 13:293-309

> Vandenberghe J, Li Y, Verdonck L, Li J, Sorgeloos P, Xu HS, Swings J (1998) Vibrios associated with Penaeus chinensis (Crustacea: Decapoda) larvae in Chinese shrimp hatcheries. Aquaculture 169:121-132

> Won KM, Park SL (2008) Pathogenicity of Vibrio harveyi to cultured marine fishes in Korea. Aquaculture 285:8-13

Wurmann CG, Madrid RM, Bruger AM (2004) Shrimp farming in Latin America: current status, opportunities, challenges and strategies for sustainable development. Aquacult Econ Manag 8:117-142

Zhang XH, Austin B (2000) Pathogenicity of Vibrio harveyi to salmonids. J Fish Dis 23:93-102

Zhong YB, Zhang XH, Chen JX, Chi ZH, Sun BG, Li Y, Austin B (2006) Overexpression, purification, characterization, and pathogenicity of Vibrio harveyi hemolysin VHH. Infect Immun 74:6001-6005

Submitted: June 1, 2010; Accepted: August 3, 2010

Proofs received from author(s): September 25, 2010 